Article

\title{
Investigating $\beta-N$-Methylamino-L-alanine Misincorporation in Human Cell Cultures: A Comparative Study with Known Amino Acid Analogues
}

\author{
Rianita van Onselen ${ }^{1, *}$, Simoné Downing ${ }^{1}$, Gabré Kemp ${ }^{2}$ and Tim Downing ${ }^{1, *}$ \\ 1 Department of Biochemistry and Microbiology, Nelson Mandela University, P.O. Box 77000, \\ Port Elizabeth 6031, Africa; Simone.Downing@mandela.ac.za \\ 2 Department of Microbial, Biochemical and Food Biotechnology, University of the Free State, \\ P.O. Box 339, Bloemfontein 9300, Africa; kempg@ufs.ac.za \\ * Correspondence: rianitavanonselen@gmail.com (R.v.O.); Tim.Downing@mandela.ac.za (T.D.); \\ Tel.: +27-41-504-2359 (R.v.O. \& T.D.)
}

Academic Editor: Amparo Alfonso

Received: 30 November 2017; Accepted: 13 December 2017; Published: 14 December 2017

\begin{abstract}
Misincorporation of $\beta-N$-methylamino-L-alanine (BMAA) into proteins has been proposed to be a mechanism of toxicity to explain the role of BMAA in neurodegenerative disease development. However, studies have shown that all detectable BMAA can be removed from proteins by SDS-PAGE purification and that the toxicity of L-canavanine cannot be reproduced in prokaryotes or in a rat pheochromocytoma cell line, strongly indicating that the misincorporation hypothesis of BMAA should be re-investigated. The aim of this study was therefore to determine if BMAA misincorporates into proteins in cells of human origin with subsequent misincorporation-type toxicity. Almost complete loss of viability in response to exposure to L-4-fluorophenylalanine and L-m-tyrosine was observed in all of the cell lines, corresponding to a concentration-dependent increase of the analogues in protein extracts from exposed cells. In contrast, BMAA exposure resulted in slight toxicity in one of the cell lines but the observed toxicity was not the result of misincorporation of BMAA into proteins, as no BMAA was detected in any of the SDS-PAGE purified protein extracts that were obtained from the cells following BMAA exposure. The results show that BMAA is not misincorporated into human proteins and that misincorporation is not a valid mechanism of toxicity.
\end{abstract}

Keywords: $\quad \beta-N$-methylamino-L-alanine; BMAA; misincorporation; analogues; m-tyrosine; L-4-fluorophenylalanine

\section{Introduction}

Exposure to $\beta$ - $N$-methylamino-L-alanine (BMAA), a non-encoded amino acid produced by cyanobacteria [1] and diatoms [2], has been linked to the development of neurodegenerative diseases such as Amyotrophic Lateral Sclerosis/Parkinsonism Dementia complex (ALS/PDC) and Alzheimer's disease [3-8]. The following mechanisms of BMAA toxicity have been proposed: excitotoxicity of the $\beta$-N-carboxy BMAA adduct that forms spontaneously in the presence of bicarbonate [9-12], the formation of toxic metabolites such as formaldehyde (capable of cross-linking proteins and nucleic acids), 2,3-diaminopropionic acid,z and methylamine upon metabolism of BMAA [13-15], and misincorporation of BMAA into proteins in place of L-serine [16]. While there is substantial evidence to support the production of toxic metabolites and the excitotoxic nature of BMAA [11,17-27] (albeit relatively weak excitotoxicity [28,29] comparable to the dietary supplement $\beta$-alanine [30]), 
misincorporation of BMAA into proteins as a mechanism of toxicity has yet to be confirmed in a natural system.

Murch et al. [31] established that most of the BMAA found in cycad flour and fruit bat tissue is associated with proteins rather than being part of the free amino acid pool, as previously thought, and that BMAA could only be removed from proteins by overnight acid hydrolysis at $110{ }^{\circ} \mathrm{C}$, prompting them to suggest misincorporation as a mechanism of toxicity. In support of this hypothesis, Dunlop et al. [16] reported a reduced concentration of protein-associated BMAA and decreased toxicity in the presence of excess L-serine in SH-SY5Y neuroblastoma cells, which they attributed to competition for protein incorporation. Similarly, Glover et al. [32] reported BMAA-protein associations in proteins produced in a cell-free Escherichia coli in vitro expression system, which they also attributed to misincorporation since BMAA could not be removed by dithiothreitol (DTT) and sodium dodecyl sulfate (SDS) washing. Interestingly, based on the observed association of the BMAA isomers $\mathrm{N}$-(2-aminoethyl)glycine and 2,4-diaminobutyric acid with proteins, Glover et al. [32] suggested that these isomers also misincorporate into proteins, although they do not suggest how this might occur. However, the inability to remove BMAA by DTT and SDS washing does not mean that BMAA is part of the primary structure of the proteins, since additional purification of proteins using sodium dodecyl sulphate-polyacrylamide gel electrophoresis (SDS-PAGE) or immobilized metal ion affinity chromatography has been shown to remove all detectable amounts of BMAA from tested proteins that previously yielded BMAA only after acid hydrolysis [33,34].

Misincorporation of non-encoded amino acids into proteins in place of standard encoded amino acids is a phenomenon that has been investigated since the 1950s [35-38]. Naturally occurring amino acid analogues are commonly found in leguminous plants, where they function as nitrogen storage compounds, allelopathic agents, and/or grazing deterrents (reviewed in [39,40]). L-canavanine is one of the most widely studied natural amino acid analogues that misincorporates in place of L-arginine in proteins [41,42]. Ingestion of large quantities of L-canavanine has been linked to the development of autoimmune disorders such as systemic lupus erythematosus (SLE) in humans and non-human primates [43-46], and to growth retardation in chicks [47]. The replacement of the $\delta$-methylene group in arginine with an oxygen in L-canavanine, results in a decrease in the $\mathrm{p} K_{\mathrm{a}}$ of arginine from 12.48, to 7.01 in L-canavanine [48]. As a result of this reduced basicity that renders L-canavanine slightly more reactive, the overall charge status of the side chain group is altered. Therefore, if L-canavanine is randomly misincorporated, the proteins are likely to have an altered three-dimensional structure and these altered proteins are recognized as foreign by a host immune system. Consequently, a host immune response is triggered, explaining the typical symptoms associated with SLE: the production of antibodies against red blood cells that results in anemia, lowered complement components in serum, the presence of antibodies to double-stranded DNA (possibly as a result of misincorporation into histones) and nuclear antigens, and the accumulation of immunoglobulin and complement components in the skin and kidneys [44].

The misincorporation of L-azetidine-2-carboxylic acid (Aze), a natural amino acid first isolated from Convallaria majalis [49], into proteins in the place of proline has also been extensively studied in a number of cell and animal models [50,51]. Proline-rich proteins such as collagen, keratin and hemoglobin are most susceptible to misfolding when Aze is present during de novo protein synthesis (reviewed in [39]). Consequently, early in utero exposure to Aze in a number of rodent models results in malformation of the lungs, inner ear, hair, vertebra, teeth, long bones, neural crest, and other structures [52-54]. Despite numerous animal studies and the discovery of Aze in commonly consumed garden beets (Beta vulgaris) [51], the role of Aze in the development of human diseases has remained relatively unexplored. However, an interesting hypothesis was raised regarding the possible contribution of Aze in the development of multiple sclerosis (MS) in humans [55]. This hypothesis was based on an unusual incidence of enzootic ataxia (also known as swayback) in at least $60 \%$ of newborn lambs in a single flock and in a single breeding season in Alberta, Canada in 1972 [56]. The specific flock was maintained on the same farm without any incidence of swayback for 
20 years. The only modification that was introduced in that specific breeding season was the addition of sugar beet-top silage, known to contain Aze, as the main source of roughage during pregnancy, lambing, and early lactation [55,56]. The symptoms of swayback include ataxia, head shaking, physical weakness, trembling, incoordination, and swaying of the hind quarters, concurrent with widespread pathological demyelination that resembles the pathological lesions observed in MS. Rubenstein therefore hypothesized that misincorporation of Aze into the myelin basic protein, specifically in the highly conserved hexapeptide sequence PRTPPP, can lead to a disruption in myelination and subsequently cause MS in humans and swayback in animals. This hypothesis is further supported by the proposed link between MS prevalence and the geographical distribution of sugar beet agriculture, specifically in Hokkaido (Japan), Finland, the Middle East, Sardinia, Alberta (Canada), and the Orkney Islands [55].

The unusual ability of fine-leaf fescue grasses (Festuca spp.) to outcompete other plants has been attributed to their ability to synthesize and excrete L-m-tyrosine (m-tyr), another non-encoded amino acid, into the rhizosphere [57]. The toxicity of m-tyr has been proposed to be the result of misincorporation of m-tyr into proteins in the place of L-phenylalanine and this has been reported to occur in prokaryotes [58,59], mammalian cell culture [60], and plants [57], with consequent growth retardation and decreased viability. It has been reported that $\mathrm{m}$-tyr and other oxidized byproducts of free L-phenylalanine can be formed in the presence of hydroxyl radical species that often accumulate under conditions of cellular stress [61,62], leading to the misincorporation of $\mathrm{m}$-tyr during de novo protein synthesis [63]. The role of these cytotoxic mistranslations in human and animal disease development remains unclear.

The toxicity observed in animals exposed to BMAA differs greatly from the toxicity associated with exposure to known amino acid analogues such as L-canavanine and Aze as described above. The replacement of L-serine by BMAA at any significant level, would have widespread and severe implications for the organism given the crucial role of L-serine in many proteins. L-Serine plays a key catalytic role in many enzymes and in hydrogen bonding within proteins, and can undergo glycosylation and its hydroxyl is a site for protein phosphorylation. The importance of L-serine in all of these critical metabolic aspects makes it unlikely that the toxicity would be limited to the central nervous system unless BMAA specifically and rapidly accumulates in these target tissues. There is some evidence to suggest that this does happen [64], but there is also evidence of liver, kidney, and muscle accumulation after intravenous administration, with less than $0.08 \%$ of the original dose being the peak concentration in the brain at two hours, an amount comparable to that seen in other tissues [65]. Similarly, fairly wide tissue distribution of BMAA in fruit bats has been reported, with much of the BMAA being in the skin and fur [66]. In non-albino mice, an accumulation of intravenously administered BMAA was noted in the eye and hair follicles and in all tissues with high cell turnover such as salivary glands, bone marrow and gastrointestinal mucosa [67]. In Rana temporaria subcutaneously administered BMAA accumulated in all pigmented tissues including eye, liver, melanocytes surrounding blood vessels and visceral organs, as well as pigmented neurons and meninges [67]. Given this distribution, and similar half-life values in the different tissues [65], toxic effects would be expected in all tissues containing BMAA if misincorporation occurred in place of the important L-serine moiety. Furthermore, BMAA is described as a late onset toxin with symptoms evident only long after exposure $[14,31,68]$. However, both free amino acid and in the protein associated BMAA has been reported to be cleared quickly from all tissues of rats that were exposed to BMAA $[15,65]$, making late-onset misincorporation toxicity highly unlikely. In contrast, the onset of gross toxicological features of misincorporation follows quickly after ingestion of amino acid analogues. These clear toxicological differences between BMAA and known amino acid analogues, suggest that misincorporation of BMAA may not occur in animals. Additionally, the reduction in growth rate caused by misincorporating amino acid analogues in bacteria, also did not occur in bacteria exposed to BMAA [34]. That the known amino acid analogues generally misincorporate in both eukaryotic and prokaryotic examples would make BMAA unique in this regard and require some 
specific differences in the seryl-tRNA synthetases for this to be the case. Nonetheless, the absence of analogue toxicity type symptoms on exposure to BMAA, and the absence of misincorporation in prokaryotes, along with the ability to remove BMAA from proteins by SDS-PAGE, suggest that BMAA may not be misincorporated into proteins, as has been hypothesiszd.

The absence of reports of BMAA toxicity in cell cultures other than neuronal cells (e.g., primary human neurons [26], rat olfactory unsheathing cells [27], human neuroblastoma SH-SY5Y [17,33]) further challenges the misincorporation hypothesis. Although Dunlop et al. [16] reported the misincorporation of BMAA in a human lung fibroblast cell line and in human umbilical vein endothelial cells, by virtue of detection of BMAA in the protein fraction, no toxicity in these cell lines was reported whereas toxicity was reported for the neuroblastoma cell line used in the same study, suggesting excitotoxicity as a mechanism. Van Onselen et al. [69] showed that differentiation of a rat pheochromocytoma cell line (PC12) with nerve growth factor, with resulting expression of glutamate receptors, was required in order to achieve BMAA toxicity, presumably via an excitotoxic mechanism. Differentiation of the same cell line was not required to observe toxicity in response to L-canavanine exposure, indicating different mechanisms of toxicity of these two compounds.

In his review published in 1962, Richmond [70] stipulated two general and fundamental requirements for a non-encoded amino acid to be considered an amino acid analogue that can be misincorporated: Firstly, if the side chain group is ionizable, it must produce the same type of ion as the side chain of the amino acid that is being replaced or it must be uncharged at physiological pH. Due to this requirement, there are only a few common side chain substitutions that permit non-encoded amino acids to be successful amino acid analogues. In terms of ionization state, these substitutions include $-\mathrm{F}$ for $-\mathrm{H}$, an $-\mathrm{O}$ - or $-\mathrm{S}$ - for $-\mathrm{CH}_{2}-$, or $-\mathrm{NH}_{2}$ for $-\mathrm{OH}$. Secondly, the analogue must be of a similar shape and size to the amino acid that is being replaced. An increase in side chain length by $-\mathrm{CH}_{2}-$ is a feature of some of the larger amino acid analogues such as ethionine for methionine (reviewed in [70]). Consequently, natural amino acid analogues that differ in size from their protein counterpart have only been identified for the larger amino acids such as L-arginine, L-phenylalanine, L-tyrosine, L-tryptophan, L-methionine and L-leucine since subtle side chain substitutions are relatively small compared to the large overall size of these amino acids. No natural amino acid analogues have been identified for the smaller amino acids such as L-alanine, L-glycine, L-serine and L-threonine, as a substitution in the side chains of these amino acids will result in a relatively large change in the overall size and shape of these amino acids.

Based on the structures of BMAA and L-serine at physiological pH (Figure 1), BMAA does not fit the requirements stipulated by Richmond [70] for non-encoded amino acids to be considered successful amino acid analogues. BMAA has an extra methyl group and an exchange of the side chain hydroxyl for an amine. In addition, 86\% of the secondary amine of BMAA is ionized at physiological pH [71], while the side chain of L-serine is uncharged. The specificity of seryl-tRNA synthetases is mainly determined by two factors: the interaction of the side chain hydroxyl group with Thr-380 in motif 3 of the enzyme and by the small size of the side-chain binding pocket [72]. Therefore, the exchange of the hydroxyl group in L-serine for the less reactive amino group in BMAA, and the increase in size by a methyl group, make the successful charging of tRNA ${ }^{\text {ser }}$ with BMAA, unlikely.

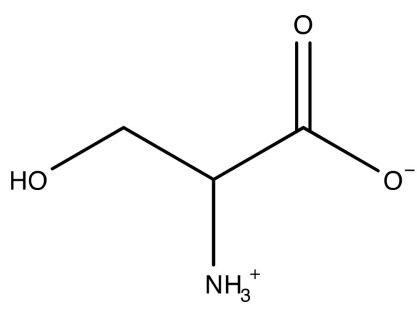

L-serine<smiles>CNCC(N)C(=O)O</smiles>

$86 \%$<smiles>CNCC([NH3+])C(=O)[O-]</smiles>

BMAA
$14 \%$

Figure 1. Illustrating the structural differences between L-serine and BMAA at physiological pH. 
The hypothesized misincorporation of BMAA, although widely mentioned as a mechanism of toxicity, thus lacks animal toxicity, in vitro, and biochemical evidence. Furthermore, the observation that BMAA in the central nervous system is predominantly in the D-form [73], makes misincorporation as a mechanism of central nervous neurotoxicity highly unlikely [74]. Evidence for non-primary protein association in favor of misincorporation also exists [34]. Furthermore, despite reports that BMAA does not misincorporate into proteins in bacteria or in a rat pheochromocytoma cell line $[34,69]$ it has been suggested that the lack of prokaryote misincorporation may not hold true in eukaryotes [75], although the authors cite Glover et al. [32] in support of their hypothesis, despite their use of a prokaryotic expression system. In this study, human cell lines were therefore used to evaluate BMAA misincorporation using both toxicological markers and amino acid compositional analysis of purified proteins from exposed cell lines, with reference to known misincorporating amino acid analogues.

\section{Results and Discussion}

The toxicity of BMAA in comparison to L-4-fluorophenylalanine (FPA) and m-tyr was determined by evaluating metabolic activity and apoptosis/necrosis in three human cell lines, so as to determine whether BMAA produced the same type of toxicity at similar concentrations as the known misincorporating amino acid analogues. The rationale was that if BMAA did not produce any toxicity, or produced a different profile of apoptosis and necrosis with increasing concentrations in any of the cell lines, the mechanism of toxicity must differ. Amino acid ratios, including the ratio of the analogue to the replaced encoded amino acid, of SDS-PAGE purified proteins from exposed cell lines were then used to determine whether any toxicity observed was the result of misincorporation of the analogue.

\subsection{Metabolic Activity}

Figure 2 shows the activity, as measured by the metabolic reduction of 3-(4,5-dimethylthiazol-2yl)-2,5-diphenyltetrazolium bromide (MTT), of FPA, m-tyr, and BMAA-exposed HepG2 (A), Caco-2 (B) and HeLa (C) cells at analogue concentrations ranging from $0.25 \mathrm{mM}$ to $2 \mathrm{mM}$. FPA decreased metabolic activity at all the concentrations tested in all cell lines. m-Tyr decreased metabolic activity in both Caco-2 and HeLa cell lines at all tested concentrations, but only at the highest tested concentration in HepG2 cells. BMAA had no significant effect on HepG2 or HeLa cells at any of the tested concentrations. Interestingly, in Caco- 2 cells, BMAA at $1 \mathrm{mM}$ and $2 \mathrm{mM}$ significantly enhanced the metabolic activity. These data indicate an absence of BMAA toxicity in these non-neuronal cell lines.

\subsection{Apoptosis/Necrosis}

The FPA and m-tyr toxicity in Caco-2 cells after $48 \mathrm{~h}$ of exposure to $2 \mathrm{mM}$ of each of the amino acids is clearly visible in Figure 3C,D. Cells appear shrunken and numbers are greatly reduced. In contrast, the BMAA treated cells (Figure 3B) at the same exposure concentration $(2 \mathrm{mM})$ appear healthy without obvious signs of cellular stress.

Following $48 \mathrm{~h}$ of treatment with BMAA, m-tyr or FPA at various concentrations, total cell counts, apoptosis, necrosis and late apoptosis/necrosis were measured for HepG2 (Figure 4) and Caco-2 (Figure 4) cells using a combination of Hoechst nuclear staining and Annexin V-FITC staining.

A concentration-dependent decrease in total cell numbers was observed for both HepG2 (Figure 4A) and Caco-2 (Figure 4A) cells exposed to m-tyr and FPA. A slight but significant decrease in cell number was observed for HepG2 cells exposed to BMAA at the highest tested concentrations $(2 \mathrm{mM})$ but BMAA did not affect cell growth and division at any of the tested concentrations in Caco-2 cells (Figure 5). The different response of cells to BMAA, compared to known misincorporating amino acid analogues, suggests that BMAA, where toxic at the highest concentration for the one cell line, might have a different mechanism of toxicity. This is supported by the absence of an effect by BMAA on MTT reduction. 

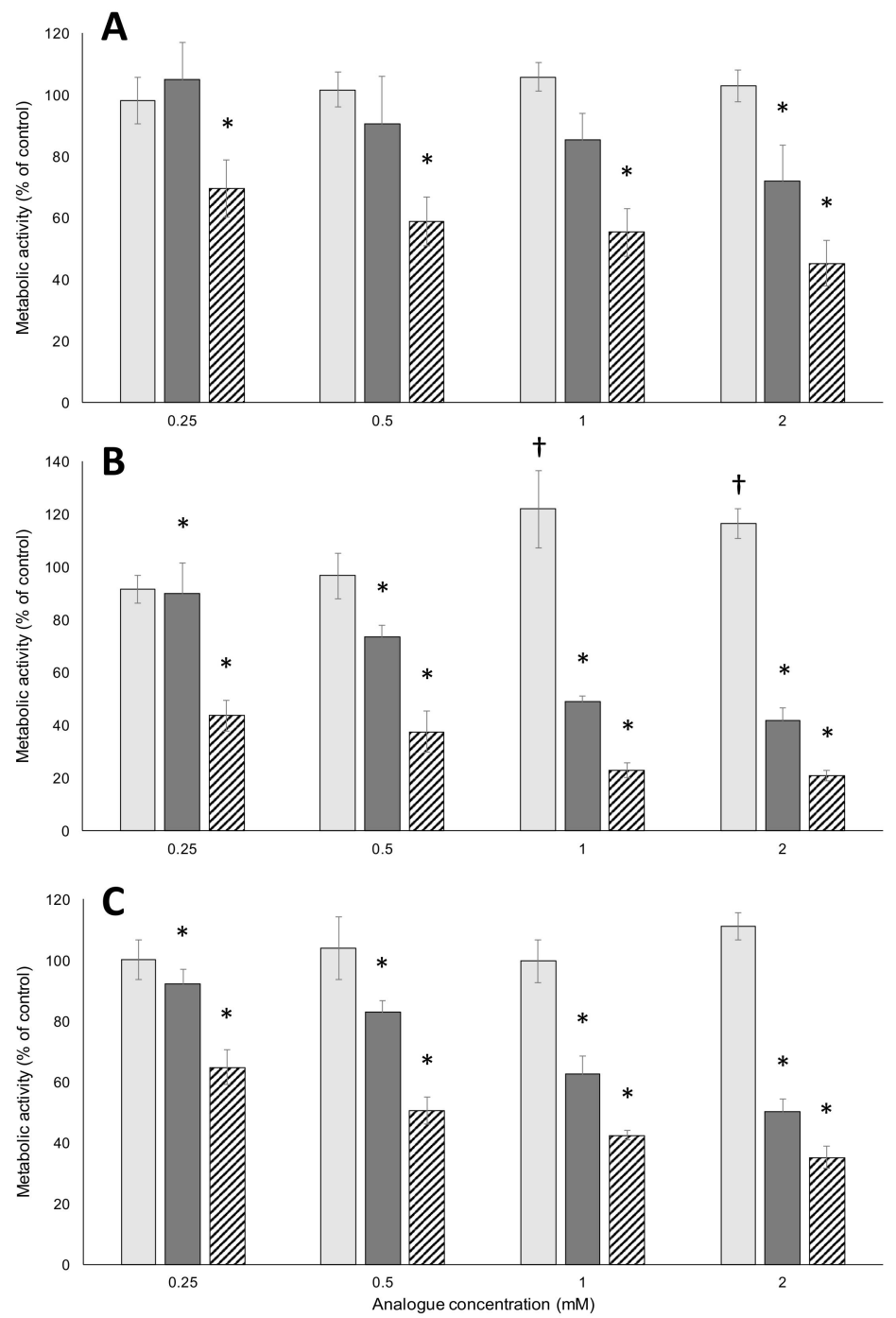

Figure 2. Metabolic activity of cells exposed to amino acids at various concentrations. HepG2 (A), Caco-2 (B) and HeLa (C) cells were exposed to BMAA (light gray bars), L-m-tyrosine (dark gray bars) and L-4-fluorophenylalanine (hatched bars) over a range of concentrations, indicated on the x-axis, for $48 \mathrm{~h}$. Metabolic activity was subsequently assayed using the MTT assay. The error bars indicate \pm standard deviation from the mean of six replicate samples $(n=6)$. An asterisk $\left(^{*}\right)$ indicates a significant decrease from vehicle-treated controls $(p \leq 0.05)$, while a dagger $(\dagger)$ indicates a significant increase from vehicle-treated controls $(p \leq 0.05)$.

FPA resulted in almost complete loss of viability when the percentages of apoptotic (Figures $4 \mathrm{~B}$ and 5B), necrotic (Figures 4C and 5C) and late apoptotic/necrotic (Figures 4D and 5D) are summed in both HepG2 and Caco-2 cells, with the greatest percentage of FPA-treated cells in the late apoptotic/necrotic phase. Similarly, HepG2 and Caco-2 cells were greatly affected by exposure to $\mathrm{m}$-tyr, but to a lesser extent than what was observed for FPA treatment due to the lesser charge/structure similarity to the encoded amino acid and consequent lower misincorporation rate (shown in Figure 6). The replacement of an aromatic hydrogen with a fluorine results in molecules with similar characteristics, as explained by Richmond [70]. Although the para-fluorine atom in FPA is larger than the para-hydrogen atom in phenylalanine, the aromatic $\mathrm{C}-\mathrm{H}$ and $\mathrm{C}-\mathrm{F}$ bond lengths are very similar, the fluorine in this position is fairly unreactive, it has electronic characteristics similar to hydrogen, and it has negligible effects on the resonance of the aromatic ring. Replacement of the para-hydrogen with a hydroxyl group results in a longer $\mathrm{C}-\mathrm{OH}$ bond length compared to $\mathrm{C}-\mathrm{H}$ or $\mathrm{C}-\mathrm{F}$, and slightly altered chemical properties, 
making m-tyr misincorporation through successful charging of $t R N A^{\text {Phe }}$, less frequent. The greatest percentage of the m-tyr exposed cells were in the late apoptotic/necrotic phase, as was seen for FPA treatment. Interestingly, BMAA induced slight but significant levels of apoptosis/necrosis in HepG2 cells (Figure 4B-D) although there was no increase in apoptosis or necrosis with increasing BMAA concentration, suggesting that the mechanism of BMAA toxicity was not a function of misincorporation. Furthermore, no toxicity was observed for BMAA-exposed Caco-2 cells in any of the measured parameters (Figure 5). Misincorporation-based toxicity, although potentially variable between cell lines for different analogues, must occur in all cell lines.

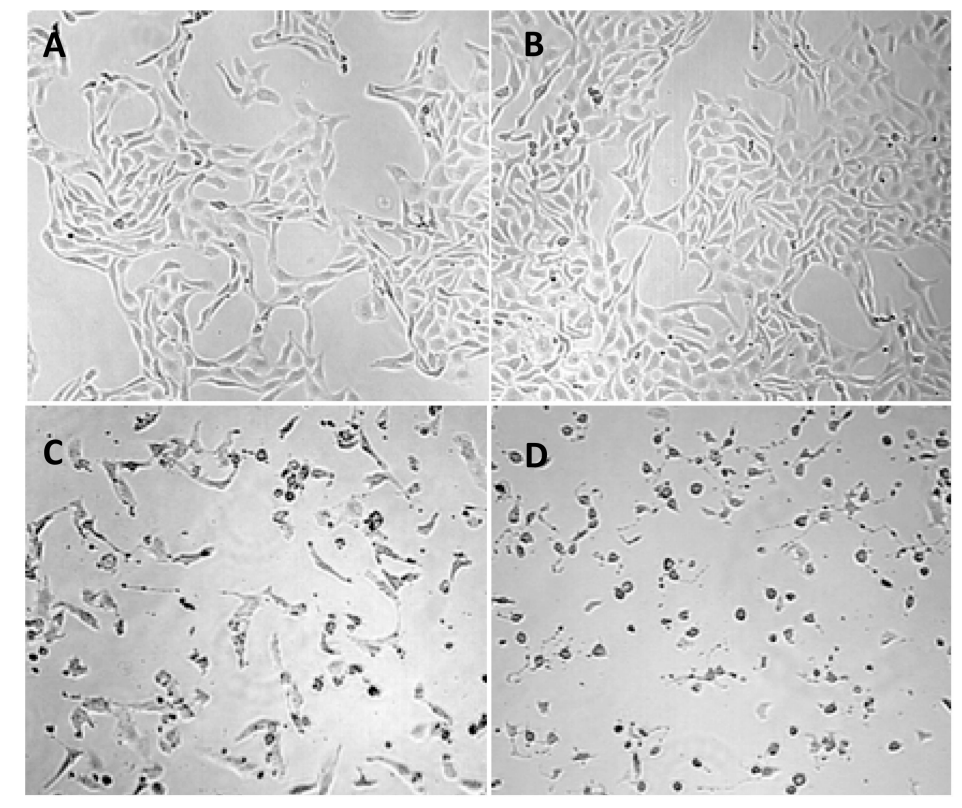

Figure 3. Representative images of Caco-2 cells following $48 \mathrm{~h}$ of exposure to the various amino acids. (A) depicts the overall shape and size of untreated control Caco-2 cells; (B) shows the same cells exposed to BMAA for $48 \mathrm{~h}$; (C) is a representative image of Caco-2 cells exposed to m-tyr; while (D) shows the same cells exposed to FPA. The images are representative of at least nine fields of views taken for six replicate samples.

\subsection{HPLC/MS-MS Analysis of Amino Acids}

For confirmation of misincorporation, the ratio of analogue to replaced encoded amino acid must increase with increasing misincorporation, which must increase for increasing concentration of the analogue in the culture medium [60]. The ratio of the replaced amino acid, relative to other encoded amino acids in proteins should also decrease with increasing exposure to misincorporating analogues. The data presented here are for SDS-PAGE purified protein extracts (required to remove surface associated BMAA [30]) from the different cell lines exposed to FPA, m-tyr, or BMAA.

\subsubsection{L-m-Tyrosine Analysis}

HPLC/MS-MS analysis of the hydrolyzed gel-purified proteins extracted from the cells exposed to m-tyr (Figure 7), shows an exposure-concentration dependent increase in the ratio of $\mathrm{m}$-tyr/L-phenylalanine in all of the exposed cell lines. This represents the increasing replacement of L-phenylalanine with m-tyr with increasing $\mathrm{m}$-tyr exposure concentration. There is also a clear trend of increasing m-tyr/L-serine and m-tyr/L-glycine ratios with increasing $\mathrm{m}$-tyr exposure concentration in all of the cell lines. Similarly, there is a decrease in the ratios of L-phenylalanine/L-serine and L-phenylalanine/L-glycine, as more of the L-phenylalanine is replaced with increasing $\mathrm{m}$-tyr exposure concentrations. 

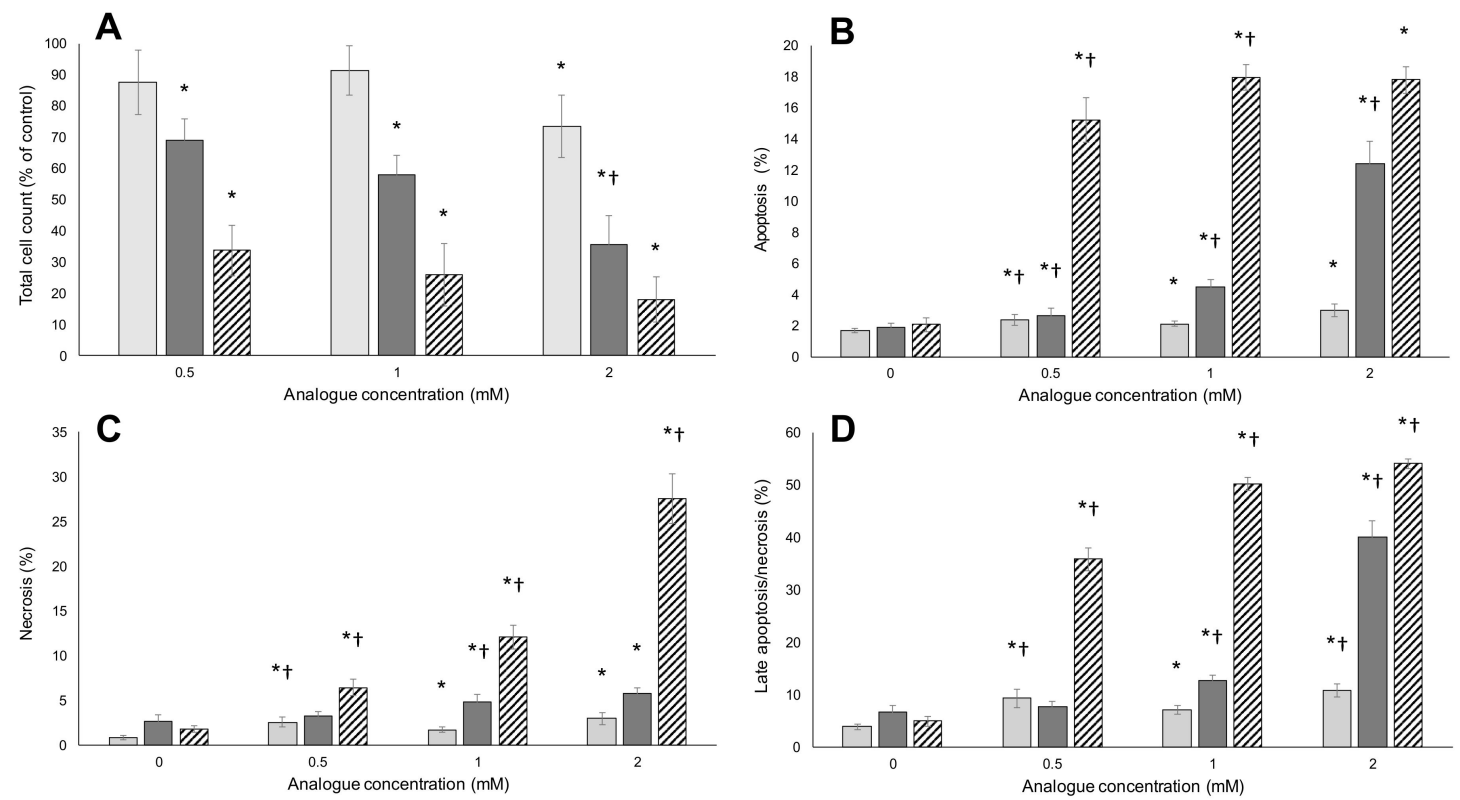

Figure 4. Total cell counts and percentage apoptotic and necrotic HepG2 cells measured after exposure to the respective amino acids. Following $48 \mathrm{~h}$ of exposure to varying concentrations of BMAA (light gray bars), m-tyr (dark gray bars) and FPA (hatched bars), total cell counts (A) were determined; as well as the percentage of apoptotic (B); necrotic (C) and late apoptotic/necrotic (D) cells. The averages of six replicate samples were plotted $(n=6)$ and the error bars denote \pm standard deviation from the mean. Asterisks $\left(^{*}\right)$ indicate significant $(p \leq 0.05)$ differences from vehicle-treated controls. A dagger $(\dagger)$ indicates a significant difference from the previous (lower) concentration $(p \leq 0.05)$.
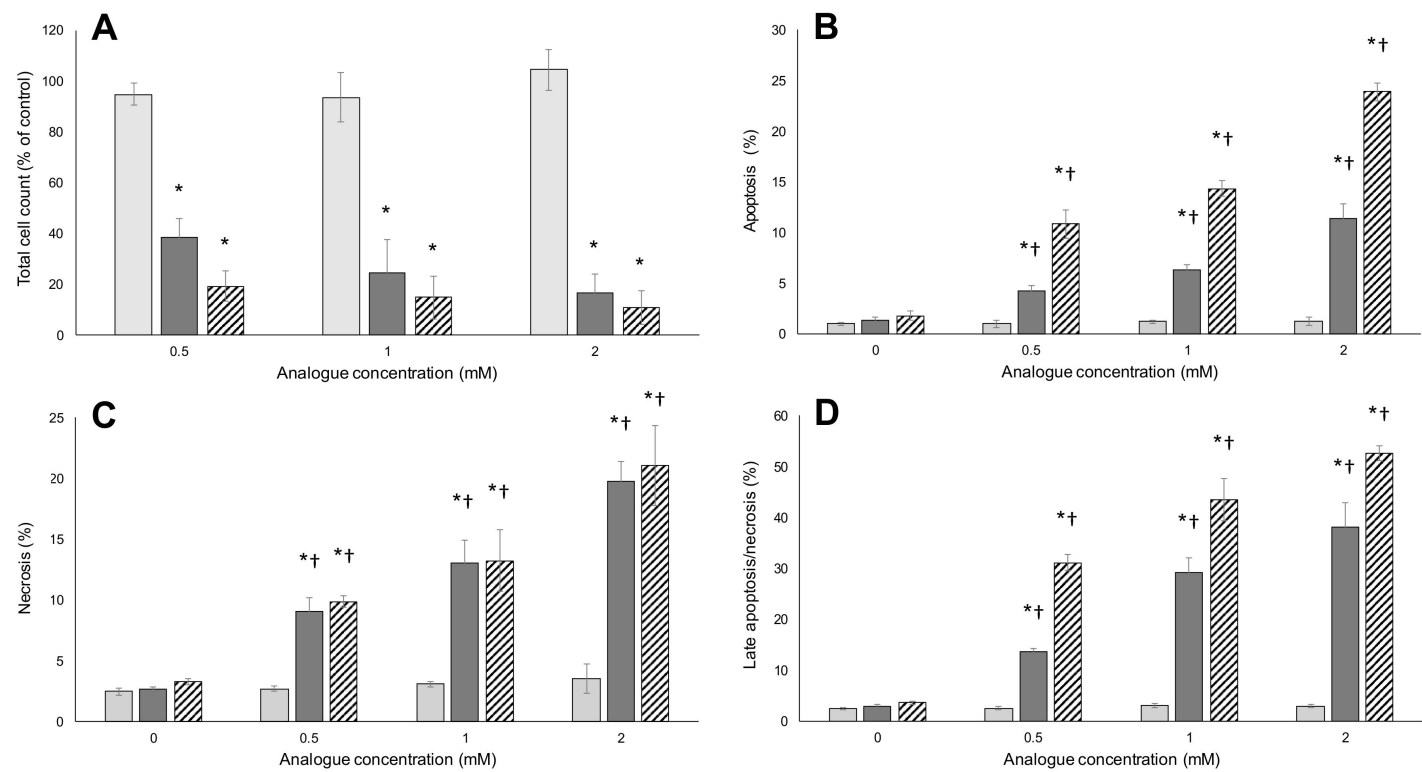

Figure 5. Total cell counts and percentage apoptotic and necrotic Caco-2 cells measured after exposure to the respective amino acids. Following $48 \mathrm{~h}$ of exposure to varying concentrations of BMAA (light gray bars), m-tyr (dark gray bars) and FPA (hatched bars), total cell counts (A) were determined; as well as the percentage of apoptotic (B); necrotic (C) and late apoptotic/necrotic (D) cells. The averages of six replicate samples were plotted $(n=6)$ and the error bars denote \pm standard deviation from the mean. Asterisks $\left(^{*}\right)$ indicate significant differences from vehicle-treated controls. A dagger $(\dagger)$ indicates a significant difference from the previous (lower) concentration $(p \leq 0.05)$. 
<smiles>NC(Cc1ccc(I)cc1)C(=O)[O-]</smiles>

L-phenylalanine<smiles>N[C@@H](Cc1ccc(F)cc1)C(=O)O</smiles>

L-4-fluorophenylalanine<smiles>[NH3+]C(Cc1ccc(O)cc1)C(=O)[O-]</smiles>

L- m-tyrosine

Figure 6. Illustrating the structural difference between L-phenylalanine and the two amino acid analogues, L-4-fluorophenylalanine and L-m-tyrosine.
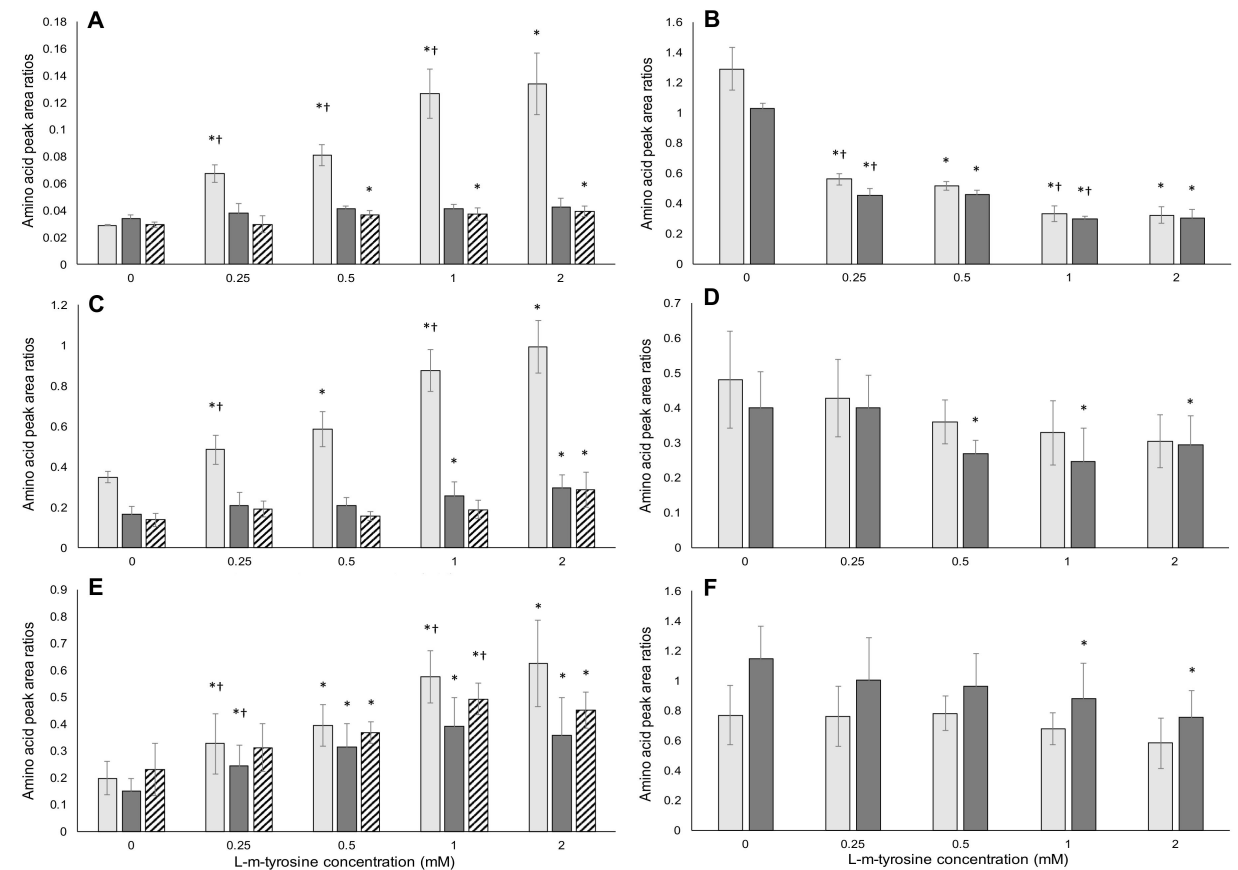

Figure 7. Amino acid analysis of cells exposed to L-m-tyrosine. The left-hand plots (A,C,E) show the ratios of $\mathrm{m}$-tyr to the replaced L-phenylalanine, and two other amino acids. The right-hand plots $(\mathbf{B}, \mathbf{D}, \mathbf{F})$ show the ratios of the replaced L-phenylalanine to other encoded amino acids. The top row of plots $(\mathbf{A}, \mathbf{B})$ is for HeLa cells; the middle row $(\mathbf{C}, \mathbf{D})$ for HepG2 cells; and the bottom row $(\mathbf{E}, \mathbf{F})$ for Caco-2 cells. The light gray bars in panels $(\mathbf{A}, \mathbf{C}, \mathbf{E})$ represent the amino acid peak area ratios of L-m-tyrosine/L-phenylalanine. The dark gray bars in $(\mathbf{A}, \mathbf{C}, \mathbf{E})$ show the $\mathrm{m}$-tyr/L-serine ratios. In A, the hatched bars indicate the $\mathrm{m}$-tyr/L-glycine ratios, whereas in $\mathrm{C}$ and $\mathrm{E}$ the hatched bars indicate 100 $\times \mathrm{m}$-tyr/L-glycine ratios. The light gray bars in $(\mathbf{B}, \mathbf{D}, \mathbf{F})$ indicate the L-phenylalanine/L-serine ratios. In (B), the dark gray bars indicate the L-phenylalanine/L-glycine ratios, while in $(\mathbf{D}, \mathbf{F})$, the dark gray bars indicate $100 \times$ L-phenylalanine/L-glycine ratios. The averages of five replicate samples were plotted $(n=5)$ and error bars denote \pm standard deviation from the mean. An asterisk $\left(^{*}\right)$ indicates a significant difference from control samples $(p \leq 0.05)$ and a dagger $(\dagger)$ indicates a significant difference from the previous (lower) concentration $(p \leq 0.05)$.

\subsubsection{L-4-Fluorophenylalanine Analysis}

As for m-tyr, there is a clear and steady increase in the FPA/L-phenylalanine ratios with increasing concentration of FPA as shown in Figure 8. Again, there is also a trend of increasing FPA/L-serine and FPA/L-glycine concentrations with increasing FPA exposure concentrations, as well as decreasing L-phenylalanine/L-serine and L-phenylalanine/L-glycine ratios as more L-phenylalanine is replaced with higher concentrations of FPA. 

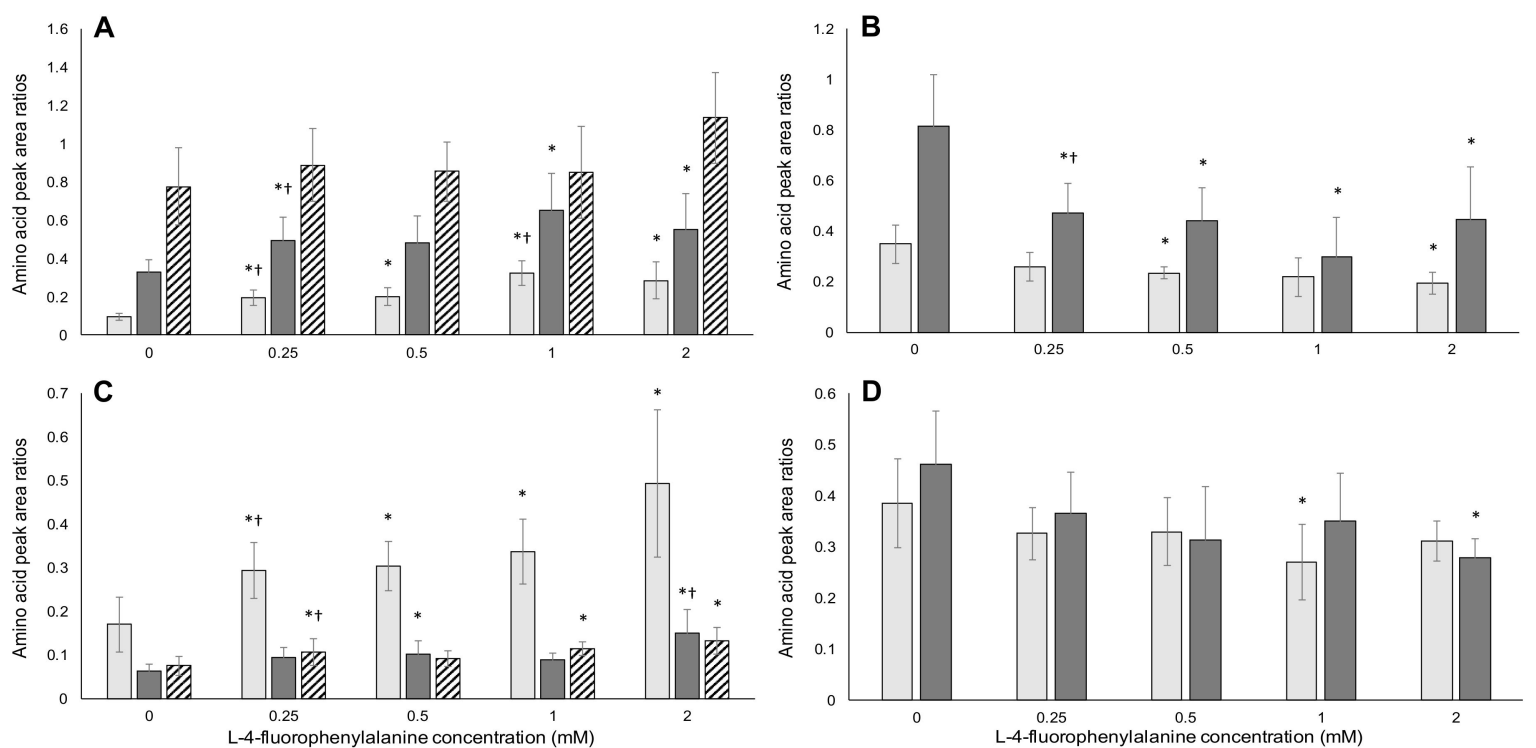

Figure 8. Amino acid analysis of cells exposed to L-4-fluorophenylalanine. The left-hand plots (A,C) show the ratios of FPA to the replaced encoded amino acid, and two other amino acids. The right-hand plots (B,D) show the ratios of the replaced L-phenylalanine to other encoded amino acids. The top row of plots $(\mathbf{A}, \mathbf{B})$ is for HepG2 cells, and the bottom row $(\mathbf{C}, \mathbf{D})$ for Caco-2 cells. The light gray bars in $(A, C)$ represent the amino acid peak area ratios of FPA/L-phenylalanine. The dark gray bars in $(\mathbf{A}, \mathbf{C})$ show the FPA/L-serine ratios, while the hatched bars indicate $1000 \times \mathrm{FPA} / \mathrm{L}$-glycine. The light gray bars in $(\mathbf{B}, \mathbf{D})$ indicate the L-phenylalanine/L-serine ratios. In (B), the dark gray bars indicate the L-phenylalanine/L-glycine ratios, while in (D) the dark gray bars indicate $100 \times$ L-phenylalanine/L-glycine ratios. The averages of five replicate samples were plotted $(n=5)$ and error bars denote \pm standard deviation from the mean. An asterisk $\left(^{*}\right)$ indicates a significant difference from control samples $(p \leq 0.05)$ and a dagger $(\dagger)$ indicates a significant difference from the previous (lower) concentration $(p \leq 0.05)$.

Both m-tyr and FPA yielded expected results for the amino acid compositional analysis, showing clear misincorporation. No BMAA was detected in any of the protein extracts from BMAA-exposed cells, at any of the exposure concentrations. Free, non-protein-associated BMAA was detected in the cell lysates of all exposed cells, confirming BMAA uptake by these cells. The L-serine/L-glycine and L-serine/L-phenylalanine ratios also did not change in BMAA-exposed cell protein hydrolysates. The changes observed in L-phenylalanine/L-serine and L-phenylalanine/L-glycine observed in m-tyr and FPA exposed cells, an indication of misincorporation of these analogues, was therefore absent in BMAA exposed cells. These data, in conjunction with the differences in cell viability and apoptosis/necrosis observed between known misincorporating analogues and BMAA, strongly suggest that BMAA does not misincorporate into proteins in these human cell lines, or that misincorporation occurs at a level that is undetectable and therefore toxicologically irrelevant. The absence of BMAA in protein extracts also confirms that the slight apoptosis and necrosis seen in BMAA-exposed HepG2 cells was not as a result of BMAA misincorporation, and suggests an additional mechanism of toxicity not related to excitotoxicity, such as the inhibition of enzymes reported by Esterhuizen-Londt et al. [76,77].

\section{Conclusions}

BMAA did not produce concentration-dependent apoptosis or necrosis, or affect the reduction of MTT in any of the tested cell lines. This is in direct contrast to the results observed for known misincorporating analogues FPA and m-tyr in the same cell lines. No BMAA was detected in purified protein extracts of BMAA-exposed cells, in direct contrast to the FPA and m-tyr detected in purified protein extracts from cells exposed to these analogues. No reduction in the encoded amino acid 
hypothesized to be replaced by BMAA was seen in any exposed cells, in direct contrast to the reduction in L-phenylalanine relative to other amino acids that was observed in m-tyr and FPA exposed cells. These data add to the growing body of evidence that BMAA is not misincorporated into proteins and that this therefore does not constitute a mechanism of toxicity.

\section{Materials and Methods}

\subsection{Cell Culture}

HepG2 cells, a human hepatocellular carcinoma cell line (Highveld Biological, Johannesburg, RSA), were routinely maintained in MEM/EBSS (Hyclone, GE Healthcare Bio-Sciences, Pittsburgh, PA, USA), with $2 \mathrm{mM}$ L-glutamine, supplemented with 10\% fetal bovine serum (FBS) (Hyclone) and penicillin-streptomycin $\left(100 \mu \cdot \mathrm{mL}^{-1}\right)$. HeLa cells, a human cervical epithelial adenocarcinoma cell line (Cellonex, Johannesburg, RSA), and Caco-2 cells, a human colorectal epithelial adenocarcinoma (Highveld Biological, Johannesburg, RSA), were routinely maintained in RPMI-1640 (Hyclone), with $2.05 \mathrm{mM}$ L-glutamine, supplemented with 10\% FBS and penicillin-streptomycin. The cells were incubated in a humidified $95 \%$ oxygen $/ 5 \%$ carbon dioxide incubator at $37^{\circ} \mathrm{C}$.

\subsection{Metabolic Activity (MTT) Assay}

HepG2, HeLa, and Caco-2 cells were seeded in 96-well plates at a density of $6.0 \times 10^{4}$ cells well ${ }^{-1}$ in $200 \mu \mathrm{L}$ culture medium and allowed to attach overnight. Following attachment, culture media were replaced with $200 \mu \mathrm{L}$ of treatment media. BMAA (Sigma Aldrich, St. Louis, MO, USA) from a $100 \mathrm{mM}$ stock in $20 \mathrm{mM}$ hydrochloric acid $(\mathrm{HCl})$, L-m-tyrosine (Alfa Aesar, Haverhill, MA, USA) from a $500 \mathrm{mM}$ stock in $1 \mathrm{M} \mathrm{HCl}$ and L-4-fluorophenylalanine (FPA) (Fluorochem, Derbyshire, $\mathrm{UK}$ ) from a $270 \mathrm{mM}$ stock in $0.5 \mathrm{M} \mathrm{HCl}$, respectively, were added to the cells in concentrations ranging from $0.25 \mathrm{mM}$ to $2 \mathrm{mM}$ in the appropriate culture medium. Vehicles were used as controls. Treatments were continued for $48 \mathrm{~h}$. Following treatments, the media were aspirated and replaced with $200 \mu \mathrm{L}$ of either MEM/EBSS or RPMI-1640, depending on the cell line, containing $0.5 \mathrm{mg} \cdot \mathrm{mL}^{-1}$ of 3-(4,5-dimethylthiazol-2-yl)-2,5-diphenyl tetrazolium bromide (MTT). The cells were incubated with the MTT media for $3 \mathrm{~h}$ at $37^{\circ} \mathrm{C}$, followed by aspiration of the media and replacement with $200 \mu \mathrm{L}$ of dimethyl sulfoxide to solubilize the formazan crystals. The absorbance was subsequently measured at $540 \mathrm{~nm}$ using a Biotek PowerWave XS microtiter plate reader (Biotek, Winooski, VT, USA).

\subsection{Phosphatidylserine Translocation (Apoptosis/Necrosis)}

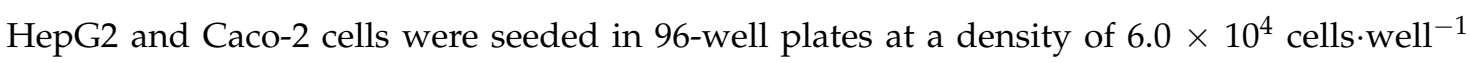
in $200 \mu \mathrm{L}$ culture medium and allowed to attach overnight. The spent medium was subsequently aspirated from each well and replaced with treatment medium. Amino acid treatments were prepared in the same way as described in Section 2.2 with concentrations ranging from 0.5 to $2 \mathrm{mM}$. Vehicles were used as controls. After $24 \mathrm{~h}$ and $48 \mathrm{~h}$ of treatment, cell numbers and apoptosis/necrosis were determined using Hoechst staining in combination with an Annexin V-FITC Kit (Miltenyi Biotec, Singapore, Singapore). Briefly, treatment media were aspirated from the wells and replaced with $100 \mu \mathrm{L}$ binding buffer, diluted with phosphate-buffered saline (PBS) as per kit instructions, containing Hoechst $\left(1 \mu \mathrm{L} \cdot \mathrm{mL}^{-1}\right)$ and Annexin $\left(10 \mu \mathrm{L} \cdot \mathrm{mL}^{-1}\right)$. The plates were incubated in the dark at room temperature for $15 \mathrm{~min}$. Propidium iodide was subsequently added in $50 \mu \mathrm{L}$ binding buffer to each well to a final concentration of $2 \mu \mathrm{g} \cdot \mathrm{mL}^{-1}$ before analyzing the cells using the ImageXpress Micro XLS (Molecular Devices).

\subsection{Exposure of Cells to Amino Acids and Preparation of Proteins for Analysis}

HeLa, HepG2 and Caco-2 cells were seeded in 12-well plates at a density of $1.5 \times 10^{5}$ cells.well $^{-1}$ in a total of $2 \mathrm{~mL}$ of culture medium specific to each cell line. The cells were left to attach overnight. After attachment, culture media were removed from the cells and treatment media were added. 
The treatments were BMAA, m-tyr, and FPA, and these were prepared from stocks as described in Section 2.2 in the appropriate culture medium. Vehicles were used as controls. The treatments were continued for $24 \mathrm{~h}$. Following treatments, the media were aspirated and the cells washed three times with PBS. The cells were subsequently collected by trypsinization and centrifugation in microcentrifuge tubes. Proteins were subsequently extracted from the cell pellets by trichloroacetic acid (TCA) extraction. Briefly, $100 \mu \mathrm{L}$ of $20 \%$ TCA (in deionized water) were added to each cell pellet and left to stand on ice for $30 \mathrm{~min}$. This was followed by $5 \mathrm{~min}$ of sonication in a $4{ }^{\circ} \mathrm{C}$ water bath sonicator. The samples were subsequently centrifuged at $20,800 \times g$ for $5 \mathrm{~min}$ at $4{ }^{\circ} \mathrm{C}$ to collect precipitated proteins. The supernatant, containing free amino acids, of each sample was collected. The protein pellets were subsequently washed twice more with $100 \mu \mathrm{L}$ of $20 \%$ TCA to ensure that all the free amino acids were removed and the TCA extracts for each sample were pooled. The TCA extracts were subsequently dried using a Savant Speedvac. The protein pellets were washed with ice-cold acetone to remove residual TCA and left to dry. The protein pellets were further purified using sodium dodecyl sulfate polyacrylamide gel electrophoresis (SDS-PAGE) as per [78]. Briefly, 10\% Tris-Glycine resolving gels with $6 \%$ stacking layers were prepared using the Bio-Rad Mini-PROTEAN ${ }^{\circledR}$ Tetra Cell system with Bio-Rad buffers and reagents. Protein pellets were resuspended in $1 \times$ loading buffer ( $0.0625 \mathrm{M}$ Tris- $\mathrm{HCl} \mathrm{pH} 6.8,10 \%$ glycerol, $2 \%$ SDS, $1 \% \beta$-mercaptoethanol, $0.01 \%$ bromophenol blue) heated to $95^{\circ} \mathrm{C}$ for $5 \mathrm{~min}$ and loaded onto the gels. A voltage of $110 \mathrm{~V}$ was applied to the gels and the proteins were allowed to migrate until the dye front migrated roughly $2 \mathrm{~cm}$ into the resolving gel. The protein band for each sample was excised from the start of the resolving gel up to the dye front and the excised gel pieces placed in $0.22 \mu \mathrm{M}$ Spin-X tubes $\left(\right.$ Corning $^{\circledR} \operatorname{Costar}^{\circledR}$ ). The gel pieces were broken up into pieces roughly $1 \mathrm{~mm} \times 1 \mathrm{~mm}$ in size. Proteins were subsequently extracted from the gel pieces by addition of $0.25 \mathrm{M}$ Tris- $\mathrm{HCl} \mathrm{pH} 6.8$ buffer with $0.1 \%$ SDS. The gel pieces were left in the solution overnight at $4{ }^{\circ} \mathrm{C}$, and the supernatant for each sample was subsequently collected by centrifugation at $20,800 \times g$ at $4{ }^{\circ} \mathrm{C}$ for $15 \mathrm{~min}$. A second aliquot of the extraction buffer was added to the gel pieces and left to stand for an hour before the supernatants were collected by centrifugation and pooled with the first aliquot. The supernatants were subsequently dried using a Speedvac. These dried protein extracts were subsequently acid hydrolyzed by adding of $100 \mu \mathrm{L}$ of $6 \mathrm{~N} \mathrm{HCl}$ to each sample in glass vials and incubating at $110^{\circ} \mathrm{C}$ for $16 \mathrm{~h}$. The hydrolysates were filtered through $0.22 \mu \mathrm{M}$ Spin- $X$ tubes before drying the samples using a Speedvac.

\subsection{HPLC/MS-MS Analysis of Amino Acids}

Dried protein hydrolysates were resuspended in $20 \mathrm{mM} \mathrm{HCl}$ and appropriately diluted for derivatization with 6-aminoquinolyl- $N$-hydroxysuccinimidyl carbamate (AQC) (Ultra AccQ-Tag derivatization kit for amino acid analysis. Waters, Milford, MA, USA). Labeled BMAA (L-BMAA-4,4,4- $\mathrm{d}_{3},{ }^{15} \mathrm{~N}_{2}$ ) (donated by the Institute of Ethnomedicine, at a purity of $99 \%$ ) was added prior to derivatization as an internal standard. Derivatized samples were immediately mixed by vortexing and subsequently incubated at $55^{\circ} \mathrm{C}$ for $10 \mathrm{~min}$ before analysis using a Shimadzu LC-20AB HPLC system coupled to a AB Sciex 4000 QTRAP ${ }^{\circledR}$ hybrid triple quadrupole ion trap mass spectrometer. Sample separation was achieved by injecting $10 \mu \mathrm{L}$ of the derivatized sample onto a Higgins (Mountain View, CA, USA) CLIPEUS ${ }^{\circledR} \mathrm{C} 18(5 \mu \mathrm{m}, 15 \mathrm{~cm} \times 3.0 \mathrm{~mm})$ analytical column held at $55^{\circ} \mathrm{C}$, with gradient elution (0-0.5 min, 10\% B; $6.0 \mathrm{~min}, 60 \% \mathrm{~B} ; 7.0 \mathrm{~min}, 95 \% \mathrm{~B} ; 11.0 \mathrm{~min}, 95 \% \mathrm{~B} ; 11.50 \mathrm{~min}, 10 \% \mathrm{~B} ; 15.0 \mathrm{~min}$, $10 \% \mathrm{~B}$ ), with mobile phases; water with $0.3 \%$ glacial acetic acid as solvent $A$ and acetonitrile with $0.3 \%$ glacial acetic acid as solvent $\mathrm{B}$, at a flow rate of $0.350 \mathrm{~mL} \cdot \mathrm{min}^{-1}$. The mass spectrometric analysis of the derivatized amino acid samples was achieved using a Turbolonspray ${ }^{\circledR}$ source in positive ion detection mode. The parameters were as follows: a source temperature of $400{ }^{\circ} \mathrm{C}$ was used, ion spray voltage was set to $5500 \mathrm{~V}$, ion source gas (nitrogen) 1 and 2 was set to $30 \mathrm{psi}$, and the curtain gas (also nitrogen) was set to 25 psi. A multiple reaction monitoring (MRM) scan type was used to measure the two most intense transitions of each of the amino acids and a dwell time of $40 \mathrm{~ms}$ was used for all transitions. The optimized collision energies and ion source potentials for each MRM transition are listed in Table 1. 
BMAA in protein hydrolysates was identified by retention time, parent ion mass, and specific and unique transitions for the analyte. The limits of BMAA detection (LoD) and quantification (LoQ) in the protein extract matrix were determined by adding isotopically labeled BMAA to appropriately diluted hydrolyzed protein extracts prior to derivatization. A peak with a signal to noise ratio $(\mathrm{S} / \mathrm{N})$ of at least 10 was selected as the LoD, while the $\mathrm{S} / \mathrm{N}$ for the LoQ was 25 . The LoD and LoQ were estimated to be $0.1 \mathrm{pg}$ and $1 \mathrm{pg}$ on column, respectively.

Table 1. The quantifier $(\mathrm{Q})$ and qualifier (q) MRM transitions of all the target amino acids with the optimized declustering potential (DP), collision energy (CE) and collision cell exit potential (CXP) for each, are listed below.

\begin{tabular}{|c|c|c|c|c|c|}
\hline Analyte & Q1 Mass $(\mathrm{m} / \mathrm{z})$ & Q3 Mass (m/z) & $\mathrm{DP}(\mathrm{V})$ & CE (V) & CXP (V) \\
\hline L-glycine Q & 246.14 & 171.00 & 61 & 29 & 14 \\
\hline L-glycine q & 264.14 & 116.20 & 61 & 63 & 18 \\
\hline L-serine Q & 276.17 & 170.90 & 71 & 37 & 28 \\
\hline L-serine $\mathrm{q}$ & 276.17 & 115.90 & 71 & 71 & 18 \\
\hline L-phenylalanine Q & 336.15 & 171.00 & 76 & 33 & 14 \\
\hline L-phenylalanine $\mathrm{q}$ & 336.15 & 115.90 & 76 & 91 & 18 \\
\hline L-m-tyrosine $Q$ & 352.24 & 171.00 & 81 & 33 & 14 \\
\hline L-m-tyrosine $\mathrm{q}$ & 352.24 & 116.00 & 81 & 91 & 18 \\
\hline L-4-fluorophenylalanine Q & 354.16 & 171.00 & 66 & 33 & 14 \\
\hline L-4-flurophenylalanine q & 354.16 & 116.00 & 66 & 89 & 18 \\
\hline L-BMAA Q & 459.20 & 171.00 & 86 & 53 & 14 \\
\hline L-BMAA q1 & 459.20 & 119.00 & 86 & 31 & 10 \\
\hline L-BMAA q2 & 459.20 & 258.00 & 86 & 33 & 22 \\
\hline L-BMAA- $4,4,4-\mathrm{d}_{3},{ }^{15} \mathrm{~N}_{2} \mathrm{Q}$ & 464.21 & 171.00 & 86 & 53 & 1 \\
\hline L-BMAA- $4,4,4-\mathrm{d}_{3},{ }^{15} \mathrm{~N}_{2} \mathrm{q} 1$ & 464.21 & 124.00 & 86 & 31 & 10 \\
\hline L-BMAA- $4,4,4-\mathrm{d}_{3},{ }^{15} \mathrm{~N}_{2}$ q2 & 464.21 & 259.20 & 86 & 33 & 22 \\
\hline
\end{tabular}

\subsection{Statistical Analysis}

Statistical significance of the data was determined using the non-parametric Mann-Whitney $U$ test $(\alpha=0.05)$.

Acknowledgments: This work was supported by the National Research Foundation of South Africa.

Author Contributions: R.v.O. and T.D. conceived and designed the experiments; R.v.O. performed the cell culture experiments; R.v.O., S.D., and G.K. conducted HPLC/MS-MS analysis; R.v.O. and T.D. wrote the paper.

Conflicts of Interest: The authors declare no conflict of interest. The funding sponsors had no role in the design of the study; in the collection, analyses, or interpretation of data; in the writing of the manuscript, and in the decision to publish the results.

\section{References}

1. Downing, S.; Banack, S.A.; Metcalf, J.S.; Cox, P.A.; Downing, T.G. Nitrogen starvation of cyanobacteria results in the production of $\beta-N$-methylamino-L-alanine. Toxicon 2011, 58, 187-194. [CrossRef] [PubMed]

2. Réveillon, D.; Séchet, V.; Hess, P.; Amzil, Z. Production of BMAA and DAB by diatoms (Phaeodactylum tricornutum, Chaetoceros sp., Chaetoceros calcitrans and, Thalassiosira pseudonana) and bacteria isolated from a diatom culture. Harmful Algae 2016, 58, 45-50. [CrossRef] [PubMed]

3. Vega, A.; Bell, E.A. $\alpha$-amino- $\beta$-methylaminopropionic acid, a new amino acid from seeds of $C y c a s$ circinalis. Phytochemistry 1967, 6, 759-762. [CrossRef]

4. Spencer, P.S.; Nunn, P.B.; Hugon, J.; Ludolph, A.C.; Ross, S.M.; Roy, D.N.; Robertson, R.C. Guam Amyotrophic Lateral Sclerosis-Parkinsonism-Dementia linked to a plant excitant neurotoxin. Science 1987, 237, 517-522. [CrossRef] [PubMed]

5. Cox, P.A.; Sacks, O.W. Cycad neurotoxins, consumption of flying foxes, and ALS-PDC disease in Guam. Neurology 2002, 58, 956-959. [CrossRef] [PubMed] 
6. Murch, S.J.; Cox, P.A.; Banack, S.A.; Steele, J.C.; Sacks, O.W. Occurrence of $\beta$-N-methylamino-L-alanine (BMAA) in ALS/PDC patients from Guam. Acta Neurol. Scand. 2004, 110, 267-269. [CrossRef] [PubMed]

7. Chiu, A.S.; Gehringer, M.M.; Welch, J.H.; Neilan, B.A. Does $\alpha$-Amino- $\beta$-methylaminopropionic acid (BMAA) play a role in neurodegeneration? Int. J. Environ. Res. Public Health 2011, 8, 3728-3746. [CrossRef] [PubMed]

8. Stommel, E.W.; Field, N.C.; Caller, T.A. Aerosolization of cyanobacteria as a risk factor for amyotrophic lateral sclerosis. Med. Hypotheses 2013, 80, 142-145. [CrossRef] [PubMed]

9. Weiss, J.H.; Choi, D.W. Beta-N-methylamino-L-alanine neurotoxicity: Requirement for bicarbonate as a cofactor. Science 1988, 214, 973-975. [CrossRef]

10. Weiss, J.H.; Chadwich, W.C.; Choi, D.W. Bicarbonate dependence of glutamate receptor activation by $\beta-N$-methylamino-L-alanine: Channel recording and study with related compounds. Neuron 1989, 3, 321-326. [CrossRef]

11. Weiss, J.H.; Koh, J.-Y.; Choi, D.W. Neurotoxicity of $\beta$-N-methylamino-L-alanine (BMAA) and $\beta$-N-oxalylamino-L-alanine (BOAA) on cultured cortical neurons. Brain Res. 1989, 497, 61-71. [CrossRef]

12. Myers, T.G.; Nelson, S.D. Neuroactive carbamate adducts of $\beta$-N-methylamino-L-alanine and ethylenediamine, detection and quantification under physiological conditions by ${ }^{13} \mathrm{C}$ NMR. J. Biol. Chem. 1990, 265, 10193-10195. [PubMed]

13. Nunn, P.B.; Ponnusamy, M. $\beta$-N-methylamino-L-alanine (BMAA): Metabolism and metabolic effects in model systmes and in neural and other tissues of the rat in vivo. Toxicon 2009, 54, 85-94. [CrossRef] [PubMed]

14. Kisby, G.E.; Spencer, P.S. Is neurodegenerative disease a long-latency response to early-life genotoxin exposure? Int. J. Environ. Res. Public Health 2011, 8, 3889-3921. [CrossRef] [PubMed]

15. Scott, L.L.; Downing, S.; Downing, T.G. The Evaluation of BMAA inhalation as a potential exposure route using a rat model. Neurotox. Res. 2017. [CrossRef] [PubMed]

16. Dunlop, R.A.; Cox, P.A.; Banack, S.A.; Rodgers, K.J. The non-protein amino acid BMAA is misincorporated into human proteins in place of L-serine causing protein misfolding and aggregation. PLoS ONE 2013, 8, e75376. [CrossRef] [PubMed]

17. Ross, S.M.; Seelig, M.; Spencer, P.S. Specific antagonism of excitotoxic action of 'uncommon' amino acids assayed in organotypic mouse cortical cultures. Brain Res. 1987, 425, 120-127. [CrossRef]

18. Zeevalk, G.D.; Nicklas, W.J. Acute excitotoxicity in chick retina caused by the unusual amino acids BOAA and BMAA: Effects of MK-801 and kynunerate. Neurosci. Lett. 1989, 102, 284-290. [CrossRef]

19. Copani, A.; Canonico, P.L.; Nicoletti, F. $\beta-N$-methylamino-L-alanine (L-BMAA) is a potent agonist of 'metabotropic' glutamate receptors. Eur. J. Pharmacol. 1990, 181, 327-328. [CrossRef]

20. Copani, A.; Canonico, P.L.; Catania, M.V.; Aronica, E.; Bruno, V.; Ratti, E.; Van Amsterdam, F.T.M.; Gavirhagi, G.; Nicoletti, F. Interaction between $\beta-N$-methylamino-L-alanine and excitatory amino acid receptors in brain slices and neuronal culture. Brain Res. 1991, 558, 79-86. [CrossRef]

21. Allen, C.N.; Spencer, P.S.; Carpenter, D.O. $\beta-N$-methylamino-L-alanine in the presence of bicarbonate is an agonist at non- $N$-methyl-D-aspartate-type receptors. Neuroscience 1993, 54, 567-574. [CrossRef]

22. Chang, Y.-C.; Chiu, S.-J.; Kao, K.-P. Beta-N-methylamino-L-alanine (L-BMAA) decreases brain glutamate receptor number and induces behavioral changes in rats. Chin. J. Physiol. 1993, 36, 79-84. [PubMed]

23. Brownson, D.M.; Mabry, T.J.; Leslie, S.W. The cycad neurotoxic amino acid, $\beta$ - $N$-methylamino-L-alanine (BMAA), elevates intracellular calcium levels in dissociated rat brain cells. J. Ethnopharmacol. 2002, 82, 159-167. [CrossRef]

24. Rao, S.D.; Banack, S.A.; Cox, P.A.; Weiss, J.H. BMAA selectively injures motor neurons via AMPA/kainite receptor activation. Exp. Neurol. 2006, 201, 244-252. [CrossRef] [PubMed] 
25. Cucchiaroni, M.L.; Viscomi, M.T.; Bernardi, G.; Molinari, M.; Guatteo, E.; Mercuri, N.B. Metabotropic glutamate receptor I mediates the electrophysiology and toxic actions of the cycad derivative $\beta-N$-methylamino-L-alanine on substantia nigra pars compacta DAergic neurons. J. Neurosci. 2010, 30, 5176-5188. [CrossRef] [PubMed]

26. Chiu, A.S.; Gehringer, M.M.; Braidy, N.; Guillemin, G.J.; Welch, J.H.; Neilan, B.A. Excitotoxic potential of the cyanotoxin $\beta$-methyl-amino-L-alanine (BMAA) in primary human neurons. Toxicon 2012, 60, 1159-1165. [CrossRef] [PubMed]

27. Chiu, A.S.; Gehringer, M.M.; Braidy, N.; Guillemin, G.J.; Welch, J.H.; Neilan, B.A. Gliotoxicity of the cyanotoxin $\beta$-N-methylamino-L-alanine (BMAA). Sci. Rep. 2013, 3, 1482. [CrossRef] [PubMed]

28. Manzoni, O.J.J.; Prezeau, L.; Bockaert, J. $\beta$-N-methylamino-L-alanine is a low-affinity agonist of metabotropic glutamate receptors. Neuroreport 1991, 2, 609-611. [CrossRef] [PubMed]

29. Pai, K.S.; Shankar, S.K.; Ravindranath, V. Billionfold difference in the toxic potencies of two excitatory plant amino acids, L-BOAA and L-BMAA: Biochemical and morphological studies using mouse brain slices. Neurosci. Res. 1993, 17, 241-248. [CrossRef]

30. Lee, M.; McGeer, P.L. Weak BMAA toxicity compares with that of the dietary supplement $\beta$-alanine. Neurobiol. Aging 2012, 33, 1440-1447. [CrossRef] [PubMed]

31. Murch, S.J.; Cox, P.A.; Banack, S.A. A mechanism of slow release of biomagnified cyanobacterial neurotoxins and neurodegenerative disease in Guam. Proc. Natl. Acad. Sci. USA 2004, 101, 12228-12231. [CrossRef] [PubMed]

32. Glover, W.B.; Mash, D.C.; Murch, S.J. The natural non-protein amino acid N- $\beta$-methylamino-L-alanine (BMAA) is incorporated into proteins during synthesis. Amino Acids 2014, 46, 2553-2559. [CrossRef] [PubMed]

33. Okle, O.; Stemmer, K.; Deschl, U.; Dietrich, D.R. L-BMAA induced ER stress and enhanced caspase 12 cleavage in human neuroblastoma SH-SY5Y cells at low neuroexcitotoxic concentrations. Toxicol. Sci. 2012, 131, 217-224. [CrossRef] [PubMed]

34. Van Onselen, R.; Cook, N.A.; Phelan, R.R.; Downing, T.G. Bacteria do not incorporate $\beta-N$-methylamino-L-alanine into their proteins. Toxicon 2015, 102, 55-61. [CrossRef] [PubMed]

35. Levine, M.; Fopeano, J.V. The use of amino acid analogues in studies of plant metabolism. Phytochem. Anal. 1953, 202, 835-850.

36. Cohen, G.N.; Adelberg, E.A. Kinetics of incorporation of $p$-fluorophenylalanine by a mutant of Escherichia coli resistant to this analogue. J. Bacteriol. 1958, 76, 328-330. [PubMed]

37. Cowie, D.B.; Cohen, G.N.; Bolton, E.T.; De Robichon-Szulmajster, H. Amino acid analog incorporation into bacterial proteins. Biochim. Biophys. Acta 1959, 34, 39-46. [CrossRef]

38. Yoshida, A.; Yamasaki, M. Studies on the mechanism of protein synthesis. Incorporation of ethionine into $\alpha$-amylase in Bacillus subtilis. Biochim. Biophys. Acta 1959, 34, 158-164. [CrossRef]

39. Rubenstein, E. Biologic effects of and clinical disorders caused by nonprotein amino acids. Medicine 2000, 79, 80-89. [CrossRef] [PubMed]

40. Rodgers, K.J.; Shiozawa, N. Misincorporation of amino acid analogues into proteins by biosynthesis. Int. J. Biochem. Cell Biol. 2008, 40, 1452-1466. [CrossRef] [PubMed]

41. Wright, J.E.; Srb, A.M. Inhibition of growth in maize embryos by canavanine and its reversal. Bot. Gaz. 1950, 112, 52-57. [CrossRef]

42. Schachtele, C.F.; Rogers, P. Mechanism of canavanine death in Escherichia coli I: Effect of canavanine on macromolecular synthesis. J. Mol. Biol. 1968, 33, 843-860. [CrossRef]

43. Malinow, M.R.; Bardana, E.J., Jr.; Goodnight, S.H., Jr. Pancytopenia during ingestion of alfalfa seeds. Lancet 1981, 1, 615. [CrossRef]

44. Malinow, M.R.; Bardana, E.J., Jr.; Pirofsky, B.; Craig, S. Systemic Lupus Erythematosus-like syndrome in monkeys fed alfalfa sprouts: Role of a nonprotein amino acid. Science 1982, 216, 415-417. [CrossRef] [PubMed]

45. Bardana, E.J., Jr.; Malinow, M.R.; Houghton, D.C.; McNutty, W.P.; Wuepper, K.D.; Parker, F.; Pirofsky, B. Diet-induced Systemic Lupus Erythematosus (SLE) in primates. Am. J. Kidney Dis. 1982, 1, 345-352. [CrossRef]

46. Roberts, J.L.; Hayashi, J.A. Exacerbation of SLE associated with alfalfa ingestion. N. Engl. J. Med. 1983, 308, 1361. [PubMed] 
47. Michelangeli, C.; Vargas, R.E. L-canavanine influences feed intake, plasma basic amino acid concentration and kidney arginase activity in chicks. J. Nutr. 1994, 124, 1081-1087.

48. Rosenthal, G.A.; Harper, L. L-homoarginine studies provide insight into the antimetabolic properties of L-canavanine. Insect Biochem. Mol. Biol. 1996, 26, 389-394. [CrossRef]

49. Fowden, L. Azetidine-2-carboxylic acid: A new cyclic amino acid occurring in plants. Biochem. J. 1956, 64, 323-332. [CrossRef] [PubMed]

50. Fowden, L.; Richmond, M.H. Replacement of proline by azetidine-2-carboxylic acid during biosynthesis of protein. Biochim. Biophys. Acta 1963, 71, 459-461. [CrossRef]

51. Carrington, M.J.; Fornieri, D.; Bartlet, C.P.; Heale, G.; Levene, C.I. Biochemical and ultrastructural study of the effects of proline analogues on collagen synthesis in 3T6 fibroblasts. J. Pharm. Pharmacol. 1985, 37, 794-801. [CrossRef] [PubMed]

52. Alescio, T. Effect of a proline analogue, azetidine-2-carboxylic acid, on the morphogenesis in vitro of mouse embryonic lung. J. Embryol. Exp. Morphol. 1973, 29, 439-451. [PubMed]

53. Joneja, M.G. Teratogenic effects of proline analogue L-azetidine-2-caboxylic acid in hamster fetuses. Teratology 1981, 23, 365-372. [CrossRef] [PubMed]

54. Rubenstein, E.; Zhou, H.; Krasinska, K.M.; Chien, A.; Becker, C.H. Azetidine-2-carboxylic acid in garden beets (Beta vulgaris). Phytochemistry 2006, 67, 898-903. [CrossRef] [PubMed]

55. Rubenstein, E. Misincorporation of the proline analog azetidine-2-carboxylic acid in the pathogenesis of multiple sclerosis: A hypothesis. J. Neuropathol. Exp. Neurol. 2008, 67, 1035-1040. [CrossRef] [PubMed]

56. Chalmers, G.A. Swayback (Enzootic Ataxia) in Alberta Lambs. Can. J. Comp. Med. 1974, 38, $111-117$. [PubMed]

57. Bertin, C.; Weston, L.A.; Huang, T.; Jander, G.; Owens, T.; Meinwald, J.; Schroeder, F.C. Grass roots chemistry: Meta-Tyrosine, an herbicidal nonprotein amino acid. Proc. Natl. Acad. Sci. USA 2007, 104, 16964-16969. [CrossRef] [PubMed]

58. Aronson, J.N.; Wemus, G.R. Effects of m-tyrosine on growth and sporulation of Bacillus species. J. Bacteriol. 1965, 90, 38-46. [PubMed]

59. Bullwinkle, T.J.; Reynolds, N.M.; Raina, M.; Moghal, A.; Matsa, E.; Rajkovic, A.; Kayadibi, H.; Fazlollahi, F.; Ryan, C.; Howits, N.; et al. Oxidation of cellular amino acid pools leads to cytotoxic mistranslation of the genetic code. eLife 2014, 3, e02501. [CrossRef] [PubMed]

60. Gurer-Ohran, H.; Ercal, N.; Mare, S.; Pennathur, S.; Orhan, H.; Heinecke, H.W. Misincorporation of free m-tyrosine into cellular proteins: A potential cytotoxic mechanism for oxidized amino acids. Biochem. J. 2006, 395, 277-284. [CrossRef] [PubMed]

61. Huggins, T.G.; Wells-Knecht, M.C.; Detorie, N.A.; Baynes, J.W.; Thorpe, S.R. Formation of o-tyrosine and dityrosine in proteins during radiolytic and metal-catalyzed oxidation. J. Biol. Chem. 1993, 268, 12341-12347. [PubMed]

62. Stadtman, E.R.; Levine, R.L. Free radical-mediated oxidation of free amino acids and amino acid residues in proteins. Amino Acids 2003, 25, 201-218. [CrossRef] [PubMed]

63. Klipcan, L.; Moor, N.; Kessler, N.; Safro, M.G. Eukaryotic cytosolic and mitochondrial phenylalanyl-tRNA synthetases catalyze the charging of tRNA with the meta-tyrosine. Proc. Natl. Acad. Sci. USA 2009, 106, 11045-11048. [CrossRef] [PubMed]

64. Karlsson, O.; Lindquist, N.G.; Brittebo, E.B.; Roman, E. Selective brain uptake and behavioral effects of the cyanobacterial toxin BMAA (beta- $N$-methylamino-L-alanine) following neonatal administration to rodents. Toxicol. Sci. 2009, 109, 286-295. [CrossRef] [PubMed]

65. Duncan, M.W.; Villacresis, N.E.; Pearson, P.G.; Wyatt, L.; Rapoport, S.I.; Kopin, I.J.; Markey, S.P.; Smith, Q.R. 2-Amino-3-(Methylamino)-Propionic Acid (BMAA) Pharmacokinetics and blood-brain barrier permeability in the rat. J. Pharmacol. Exp. Ther. 1991, 258, 27-35. [PubMed]

66. Banack, S.A.; Murch, S.J.; Cox, P.A. Neurotoxic flying foxes as dietary items for the Chamorro people, Marianas Islands. J. Ethnopharamacol. 2006, 106, 97-104. [CrossRef] [PubMed]

67. Karlsson, O.; Berg, C.; Brittebo, E.B.; Lindquist, N.G. Retention of the cyanobacterial neurotoxin $\beta-N$-methylamino-L-alanine in melanin and neuromelanin-containing cells-A possible link between Parkinson-dementia complex and pigmentary retinopathy. Pigment Cell Melanoma Res. 2008, 22, 120-130. [CrossRef] [PubMed] 
68. Spencer, P.S. Guam ALS/Parkinsonism-Dementia: A long-latency neurotoxic disorder caused by "Slow Toxin(s)" in food? Can. J. Neurol. Sci. 1987, 14, 347-357. [CrossRef] [PubMed]

69. Van Onselen, R.; Venables, L.; Van De Venter, M.; Downing, T.G. $\beta$-N-methylamino-L-alanine toxicity in PC12: Excitotoxicity vs. Misincorporation. Neurotox. Res. 2017. [CrossRef] [PubMed]

70. Richmond, M.H. The effect of amino acid analogues on growth and protein synthesis in microorganisms. Bacteriol. Rev. 1962, 26, 398-420. [PubMed]

71. Nunn, P.B.; O'Brien, P. The interaction of beta-N-methylamino-L-alanine with bicarbonate: An 1H-NMR study. FEBS Lett. 1989, 251, 31-35. [CrossRef]

72. Härtlein, M.; Cusack, S. Structure, function and evolution of seryl-tRNA synthetases: Implications for the evolution of aminoacyl-tRNA synthetases and the genetic code. J. Mol. Evol. 1995, 40, 519-530. [CrossRef] [PubMed]

73. Metcalf, J.S.; Lobner, D.; Banack, S.A.; Cox, G.A.; Nunn, P.B.; Wyatt, P.B.; Cox, P.A. Analysis of BMAA enantiomers in cycads, cyanobacteria and mammals: In vivo formation and toxicity of D-BMAA. Amino Acids 2017, 49, 1427-1439. [CrossRef] [PubMed]

74. Nunn, P.B. 50 years of reseach on $\alpha$-amino- $\beta$-methylaminopropionic acid ( $\beta$-methylaminoalanine). Phytochemistry 2017, 144, 271-281. [CrossRef] [PubMed]

75. Metcalf, J.S.; Dunlop, R.A.; Powell, J.T.; Banack, S.A.; Cox, P.A. L-Serine: A naturally-occurring amino acid with therapeutic potential. Neurotox. Res. 2017. [CrossRef] [PubMed]

76. Esterhuizen-Londt, M.; Pflugmacher, S.; Downing, T.G. The effect of $\beta$ - $N$-methylamino-L-alanine (BMAA) on oxidative stress response enzymes of the macrophyte Ceratophyllum demersum. Toxicon 2011, 57, 803-810. [CrossRef] [PubMed]

77. Esterhuizen-Londt, M.; Wiegand, C.; Downing, T.G. $\beta-N$-methylamino-L-alanine (BMAA) uptake by the animal model, Daphnia magna and subsequent oxidative stress. Toxicon 2015, 100, 20-26. [CrossRef] [PubMed]

78. Laemmli, U.K. Cleavage of structural proteins during the assembly of the head of bacteriophage T4. Nature 1970, 227, 680-685. [CrossRef] [PubMed]

(C) 2017 by the authors. Licensee MDPI, Basel, Switzerland. This article is an open access article distributed under the terms and conditions of the Creative Commons Attribution (CC BY) license (http://creativecommons.org/licenses/by/4.0/). 